
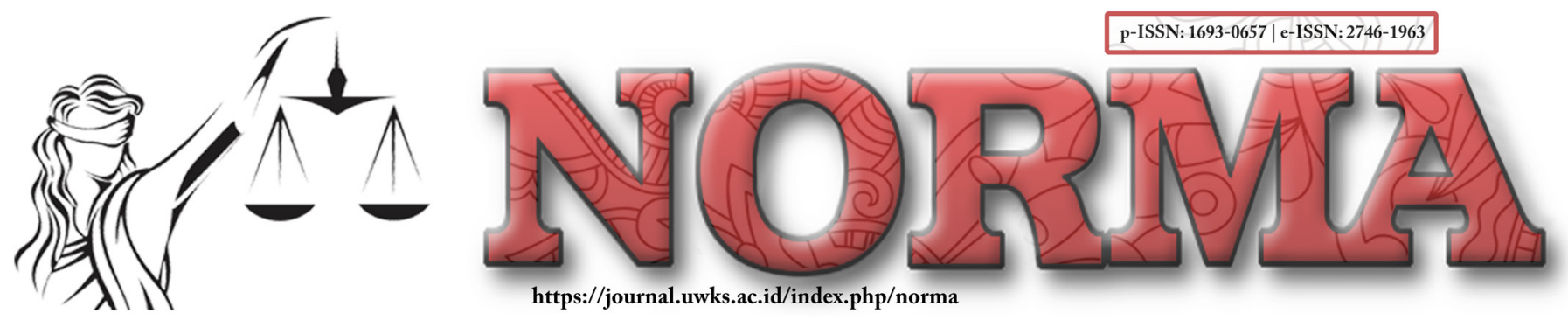

\title{
Flats for Foreigner After the Issuance of the Omnibus Law in Indonesia
}

\author{
Galang Fauzan Prawinda; Arjie Sukmawijaya Arpian Putra \\ Law Faculty, Universitas Airlangga \\ e-Mail: fauzan12prawinda@gmail.com; arjie.sukmawijaya.arpian.2019@fh.unair.ac.id
}

\begin{abstract}
:
This research is normative juridical research that uses a statutory approach. The government has issued its latest policy, namely, Law number 11, the year 2020, concerning omnibus law, which regulates foreigner property rights regarding flats. Based on this regulation, a foreigner can have ownership rights over the flats. However, it results in problems because a nationality principle is regulated in Indonesian Land Law, prohibiting foreigners from having ownership rights. In Minister of agricultural regulation held that foreigners can only own flats unit based on usage rights. The result of this study, a foreigner, can have an apartment through the transfer of ownership such as buying and selling, grants, auctions, and so on, but it is only a right to use, not an ownership right. Foreigners who wish to own an apartment unit must meet the requirements and restrictions to maintain and prioritize Indonesian citizens' interests.
\end{abstract}

Keywords: Flats; Foreigner; Omnibus Law.

Article's History:

Received:

February 16, 2021;

Peer-Reviewed:

February 24, 2021;

Accepted:

February 27, 2021;

Published:

March 5, 2021.

DOI:

10.30742/nlj.v18i1.1289

\section{INTRODUCTION}

The increasing population in urban areas has consequences for the government to provide decent and healthy housing or shelter. In line with the development of the national economy, the development of the Flats is increasing; this is one of the characteristics of the improving and increasing national economy. With a relatively affordable price and close to the main road, this is perfect for busy community activities. This also eliminates society's perception that apartments are owned by middle and upper-class people and flats for low-income people. ${ }^{1}$

According to Law Number 2 of 2011 concerning Flats (from now on referred to as UURS), a flat is a multi-storey building built in an environment divided into functionally structured sections. Each can be owned and used separately, especially for dwellings equipped with standard parts, everyday objects, and common land. ${ }^{2}$

${ }^{1}$ M Shafiyuddin Wafi and R Suharto, “Perolehan Sertipikat Hak Milik Atas Satuan Rumah Susun (Studi Di Star Apartemen)" Diponegoro Law Journal. 5.3 (2016): 3.

2 Anggit Atma Yuwita, "Legal Action for Pre-Project Selling Based Buyers Whose Apartment Specification Have Changed Without Prior Approval" Norma. 17.3 (2021): 70. 
Regarding ownership of a flat unit, the form of ownership known is a Certificate of Ownership on the Flats (from now on referred to as SHMRS). SHMRS is a form of ownership granted to the right holder of the Flats. The structure of ownership rights to flats must be distinguished from ownership rights to houses and land in general. According to Article 46 of the UURS, the flat unit's right of ownership is the flat unit's right of ownership, separate with joint rights over ordinary shares, everyday objects, and common land. The definitions of some of the terms mentioned in Article 46 UURS above can be found in the UURS explanation, namely:

a. Communal land is a plot of land with rights or leasehold land for buildings used based on joint ownership. Separately on which an flat stands and the boundaries are determined in the building construction permit requirements;

b. A joint part is part of a flat owned separately for shared use in a unitary function with flat units. These include foundations, columns, beams, walls, floors, roofs, gutters, stairs, elevators, hallways, channels, pipes, electricity, gas, and telecommunications networks;

c. Everyday objects are not part of a flat but pieces that are not separately owned for sharing. Among other things are meeting rooms, plants, gardening buildings, social facilities buildings, places of worship, playgrounds, and parking lots that are separate or integrated into the flat building structure.

The national land law is known as the principle of nationality, regulated in Law No. 5/1960 on Agrarian Principles (referred to as UUPA). Foreign citizens (WNA) and foreign legal entities are not allowed to have rights over certain land as regulated in Article 9 paragraph (1) of the UUPA, especially land ownership rights and Building Use Rights. ${ }^{3}$ Land rights that foreigners may own are usage rights and/or lease rights for buildings. ${ }^{4}$

In the UURS, ownership of flat units can be seen in Article 1, number 16, and number 17, which states that each person is an individual or a legal entity. Legal entities are those established by Indonesian citizens whose activities are in managing housing and residential areas. This is different from Law Number 11 of 2020 concerning Job Creation (from now on referred to as the Job Creation Law); Article 144 paragraph (1) stipulates that ownership of flat units can be given to:

a. Indonesian citizens;

b. Indonesian legal entities;

c. Foreign citizens who have a license following the provisions of laws and regulations;

3 Farah Herliani, Ida Nurlinda, and Betty Rubiati, "Peralihan Hak Milik Menjadi Hak Pakai Atas Sarusun di Atas Tanah HGB Kepada Orang Asing Dihubungkan Dengan PP No. 103 Tahun 2015/Kepala BPN No. 29 Tahun 2016" ACTA DIURNAL Jurnal Ilmu Hukum Kenotariatan. 2.1 (2018): 70.

4 Siti Mutiah, "Hak Kepemilikan atas Satuan Rumah Susun di atas Tanah Hak Guna Bangunan yang Berdiri di atas Tanah Hak Milik" Al-Qanun: Jurnal Pemikiran dan Pembaharuan Hukum Islam. 21.1 (2018): 150. 
d. Foreign legal entities that have representatives in Indonesia; or

e. Representatives of foreign countries and international institutions that are located or have representatives in Indonesia.

This regulation creates a legal contradiction with the existing principle of nationality. So, it is necessary to have rules regarding the requirements for ownership of flat units for the five groups. In the Job Creation Law, or what is commonly called the Omnibus Law, no rules regulate what land rights a foreigner can have.

\section{RESEARCH METHOD}

This research is a normative legal research, with a statutory approach (statute approach) and conceptual approach. This approach is used because the discussion in this study will refer to the Law and the concept related to the issue.

\section{DISCUSSION}

To support programs to increase Indonesian cooperation with other countries and increase the property industry in Indonesia, which will impact the number of foreign citizens working and building businesses in Indonesia, indirectly growing demand for housing, the government's role as an organ is needed. Those who have the right to issue policies that can support business actors (domestic or foreign) by creating social conditions facilitating licensing and requirements by speeding up the process. ${ }^{5}$ With these aims and objectives, the government issued a Job Creation Law. There is a regulation regarding ownership rights of flat units in Indonesia, as stated in Article 144 paragraph (1) that the ownership rights to flat units can be given to:
a. Indonesian citizens;
b. Indonesian legal entities;
c. Foreign citizens who have a license following the provisions of the legislation;
d. Foreign legal entities that have representatives in Indonesia; or;
e. Representatives of foreign countries and international agencies that are located or have representatives in Indonesia.

From the provisions mentioned earlier, it can be explained that ownership rights to flat units can be given to foreign citizens who have a permit under the laws and regulations' conditions. The property rights of these flat units can be transferred, and/ or guaranteed. This provision does not explain what land rights a foreign citizen can own, considering that there is a mention of ownership rights over flat units, meaning that foreign citizens can have ownership rights over flat units over rights to land in the form of property rights or ownership rights. Building rights. Based on Article 145 of the Omnibus Law, it is stated that the flats are built on building use rights so that it is

5 Listyowati Sumanto, "Kepemilikan Rumah Tempat Tinggal Atau Hunian Oleh Orang Asing Yang Berdomisili Di Indonesia” Jurnal Legislasi Indonesia. 14.04 (2017): 460. 
as if foreign citizens can have ownership rights over the flat units above the Building Use Rights. The provisions of the law on Job Creation can be a problem considering that it overlaps with the Basic Agrarian Law (UUPA) number 5 of 1960 and other laws and regulations relating to property rights to flat units.

Before discussing the land rights of flat units for foreign citizens, foreign nationals' concept of a house with homeownership will be explained, namely, a building. This can be likened to the use of dwellings for Indonesian citizens. ${ }^{6}$ Residence can be in the form of a house or flats, for a place to live in the state of a home, it is already attached to our memory how its structure and use is, while for flats not everyone knows it. A flat is a multi-stored building where the building contains a private ownership system, and there is joint ownership between the flat residents. Given that flats have a shared aspect, the existence of flats as an alternative to housing feels very efficient; there are three aspects, namely as follows: ${ }^{7}$

a. The flat is a multi-stored building with a development direction vertically or horizontally, where each part can be owned and used separately;

b. A flat is building ownership which consists of several units; and

c. The condominium is a joint property with both buildings and shared facilities. Referred to as shared building and facilities is a shared part of a flat that is not separated for shared use in one functional unit with the flat unit. Some examples of this shared section consist of lobbies, corridors, stairs, power lines, elevators, etc. ${ }^{8}$

This shared facility is a shared right for its residents, both Indonesian citizens and foreign citizens. A foreign citizen is defined as a person who lives in a country and is not a citizen of that country. ${ }^{9}$ The definition of foreigners can also be seen from Article 1 of Law Number 24 of 2015 concerning Amendments to Law Number 23 of 2006 concerning population administration, emphasizing that foreigners are not Indonesian citizens. The same thing is also mentioned in Law Number 6 of 2011 concerning Immigration. Foreigner who is domiciled in Indonesia is a foreigner who in Indonesia carries out economic activities and which he regularly does or at any time, he will need a house to live in or occupy during his work. Such circumstances make them need a place to live as. ${ }^{10}$

Foreign nationals who need a place to live in Indonesia can obtain a place to live where their land rights must meet material and formal requirements in obtaining the residence. Material requirements must pay attention to legal subjects' legal conditions,

6 Sri Endang and Rumingtyas, "Analisis Hukum Terhadap Kepemilikan Rumah Tempat Tinggal/ Hunian oleh Orang Asing yang Berkedudukan di Indonesia" Jurnal de Jure. 10.Ii (2018): 64..

7 Ibid.

8 Taufik Jan Latamu, "Kedudukan Hak Milik Atas Satuan Rumah Susun Sebagai Jaminan Kredit Perbankan" Lex Privatum. 3.2 (2015): 190.

9 R Subekti Tjitrosoedibio, Kamus Hukum (Pradnya Paramita, 2012) 45.

${ }^{10}$ Adrian Sutedi, Tinjauan Hukum Pertanahan (Jakarta: Pradnya Paramita, 2009) 268. 
which can receive land rights or property rights over flat units to take legal actions. ${ }^{11}$ The issue of ownership rights to a flat unit is a subject that meets the requirements as the holder of land rights, while the object, in this case, is a flat unit. ${ }^{12}$ Formal requirements are conditions held in the context of registering a transfer of rights, which is to obtain a certificate as proof of rights. Standard requirements are related to the procedural transfer of ownership rights over the syringe, while the material conditions are offenses contained in the statutory regulations that must be fulfilled. The formal requirements also include the process of transferring and registering land rights, either for the first time or for data maintenance. ${ }^{13}$

Ownership rights to sarusun are objects of land registration as stated in Article 9 paragraph (1) of Government Regulation Number 24 of 1997 concerning Land Registration. Ownership of land and building that foreign nationals can obtain is limited to usage rights and lease rights; this is based on Article 42 of Law Number 5 of 1960 concerning Basic Agrarian Regulations (UPPA), one of them who can have usufructuary rights is a foreigner who is domiciled in Indonesia. Based on Article 2 of Government Regulation Number 103 of 2015 concerning Ownership of Residential or Occupancy by Foreigners Domiciled in Indonesia, it states that:

a. A foreigner can own a house to live or occupy with the Right to Use;

b. A foreigner who can own a residential or residential house as referred to in paragraph (1) is a Foreigner who holds a residence permit in Indonesia following the provisions of statutory regulations;

c. If the foreigner dies, the house or dwelling as referred to in paragraph (2) can be inherited;

d. If the heir, as referred to in paragraph (3), is a foreigner, the heir must have a residence permit in Indonesia following laws and regulations.

The government regulation also emphasizes that foreign citizens who are allowed to own a house or occupancy do provide benefits, do business, work or invest in Indonesia. $^{14}$

Based on this, foreign citizens can only have ownership rights to flat units on land use rights. ${ }^{15}$ Given that Law Number 11 of 2020 concerning Omnibus Law does not explain what land foreign citizens can own. Foreign nationals can't have ownership rights over land or building use rights; this is contrary to the provisions contained

11 Urip Santoso, Hukum Perumahan (Jakarta: Kencana Media, 2016) 355.

12 Rizky Ayu Nataria El Chidtian, "Hak Milik Atas Satuan Rumah Susun untuk Pertokoan yang Berasal dari Perjanjian Bangun Guna Serah Atas Tanah Hak Pengelolaan” Yuridika. 28.1 (2013): 60.

13 Rondonuwu and Giovanni, "Kepastian Hukum Peralihan Hak Atas Tanah Melalui Jual Beli Berdasarkan PP Nomor 24 Tahun 1997 Tentang Pendaftaran Tanah” Lex Privatum. 5.4 (2017): 55.

14 Mira Novana Ardani, "Kepemilikan Hak Atas Tanah Bagi Orang Asing Di Indonesia" Law Reform. 13.2 (2017): 204.

15 Indah Jacinda, Jason Jusuf, and Verlin Ferdina, “Penguasaan Tanah Di Indonesia Oleh Warga Negara Asing Melalui Perkawinan Campuran Dalam Falsafah Hukum” ADIL: Jurnal Hukum. 9.2 (2019): 61. 
in the UUPA and the principles contained therein. The Principle of Nationality, determines that only Indonesian citizens can have rights to land-based on ownership rights without differentiating between male and female. In contrast, foreign citizens are prohibited from having property rights; this is emphasized in Article 26 paragraph (2) UUPA. ${ }^{16}$

Based on the intent and purpose of issuing the omnibus law, it attracts investors and facilitates licensing in Indonesia; however, loosening the property ownership rules for foreign citizens will harm the country's property business. Due to the loosening of regulations regarding ownership of flat units, the lousy impact will cause property prices to rise due to increased demand. When foreign nationals are free to own property in Indonesia, it causes small developers to go out of business because it causes land prices to rise.

The Ministry of Agrarian Affairs and Spatial Planning and the National Land Agency issued residential ownership rules for foreigners. The regulation is the Regulation of the Minister of ATR / Head of BPN number 13 of 2016 concerning Procedures for Granting, Releasing or Transfer of Rights to Residential or Residential House Ownership by Foreigners Domiciled in Indonesia. This rule is a follow-up to Government Regulation Number 103 of 2015 concerning Ownership of Residential or Residential Homes by foreigners domiciled in Indonesia. Article 3 number 1 Regulation of the Minister of Agrarian Affairs Number 29 of 2016 concerning the procedures for Granting, Releasing, or Transfer of Rights to Ownership of Residential Homes or Occupations of Foreigners Domiciled in Indonesia affirms that "Foreigners who hold a residence permit in Indonesia are following the provisions of laws invitation, can have a house for residence or occupancy with Right to Use."

If detailed in outline based on Government Regulation Number 103 of 2015 are as follows:

a. Foreign citizens can own one house or residence; it can be in the form of a flat unit or the form of a house built on land use rights;

b. The right to use on state land or the right to use over the land of ownership rights granted by the holder of the right of ownership with the deed of the official who makes the land deed can be used as a base for the right to an independent house;

c. It must be recorded in the land book and certificate if the agreement grants usufructuary rights over the ownership rights. 25 (twenty-five) years is the maximum period for granting usufructuary rights over ownership rights, which cannot be extended but can be renewed within 20 (twenty) years. This must be following the agreement of the parties, and which becomes a note that the foreign citizen is still domiciled in Indonesia;

\footnotetext{
${ }^{16}$ Sri Hajati, Politik Hukum Pertanahan (Surabaya: Airlangga University Press, 2017) 13.
} 
d. If the house or condominium is established on use rights over state land or based on an agreement with a right holder not domiciled in Indonesia, then within 1 (one) year, the foreign citizen is obliged to transfer or relinquish his land and house rights to another party have qualified;

e. If within 1 (one) year it is not released or transferred to another party, the right to use the state land will be auctioned off, while the right to use over the land that is right of ownership will again become the owner of the right to the said land.

Foreign citizens can own flat units built on land use rights. In terms of their presence in Indonesia, these foreigners can be divided into 2 (two) groups, namely foreign citizens who reside in Indonesia permanently proven by a residence permit and foreigners who are in Indonesia at any time; it must be verified with a visit permit. or immigration permit.

The omnibus law also regulates the rights to ownership of units, houses, and structures that can also be given to foreign legal entities with representatives in Indonesia. Based on land law, foreign legal entities are contained in UUPA article 42 letter $\mathrm{d}$, which states that foreign legal entities with representatives in Indonesia can hold rights to land, namely usage rights. This distinguishes the right to use from other land rights that do not allow foreign legal entities to have ownership over lands such as property rights, HGU, or HGB. Likewise, representatives of foreign countries and "international institutions" located or have representatives in Indonesia can obtain use rights based on Government Regulation Number 40 of $1996 .{ }^{17}$

No regulations govern the ownership of flat units designated for foreign legal entities and state representative bodies, and international agencies that do have representatives and are domiciled in Indonesia. When viewed from the regulations that have been mentioned above, public and private legal entities can have use rights, while for flat units, in the Government Regulation concerning "flat" and "Government" regulations regarding "House Ownership" a place "dwelling" by foreigners, does not regulate these public and private legal entities. In this regard, foreign legal entities and state representative bodies can own land-use rights as foreign citizens. The legal entity and the representative body can have a flat unit with the condition that the flat structure stands on land use rights.

\section{CLOSING}

\section{Conclusion}

Based on Omnibus Law, which regulates property rights to flat units, this regulation still does not provide clarity regarding the basis of land rights that foreigner

17 Iwan Permadi, "Kedudukan Badan Hukum Asing Dalam Pemilikan Tanah Di Indonesia" Jurnal Wacana. 15.4 (2012): 41. 
can own for flat units. The arrangement regarding the ownership of flat units refers to Government Regulation Number 103 of 2015 concerning Ownership of Residential or Residential Houses by Foreigners who are domiciled in Indonesia. Based on this regulation, the status of land rights of flat units that foreign nationals can own is the right to use. Foreign nationals who wish to own a flat unit must meet the requirements and restrictions that must be obeyed to maintain and prioritize Indonesian citizens' interests. Government regulations have provided limits on ownership of land and residential houses by foreign nationals domiciled in Indonesia and ensure that land ownership is utilized correctly.

\section{Recommendation}

Law Number 11 of 2020 should require implementing regulations regarding ownership of property rights to flat units by foreigner; these regulations must be issued by the Minister of Agrarian Affairs and Spatial Planning/National Land Agency. In controlling foreigner, foreigner should be provided with rules regarding the limits for purchasing flat units and the minimum limit for the land price in a particular area.

\section{REFERENCES}

Ardani, Mira Novana. "Kepemilikan Hak Atas Tanah Bagi Orang Asing Di Indonesia." Law Reform 13.2 (2017): 204-216.

Atma Yuwita, Anggit. "Legal Action for Pre-Project Selling Based Buyers Whose Apartment Specification Have Changed Without Prior Approval." Norma 17.3 (2021): 69-79.

Chidtian, Rizky Ayu Nataria El. "Hak Milik Atas Satuan Rumah Susun untuk Pertokoan yang Berasal dari Perjanjian Bangun Guna Serah Atas Tanah Hak Pengelolaan." Yuridika 28.1 (2013): 59-74.

Endang, Sri, and Rumingtyas. "Analisis Hukum Terhadap Kepemilikan Rumah Tempat Tinggal/Hunian oleh Orang Asing yang Berkedudukan di Indonesia." Jurnal de Jure 10.Ii (2018): 62-72.

Hajati, Sri. Politik Hukum Pertanahan. Surabaya: Airlangga University Press, 2017.

Herliani, Farah, Ida Nurlinda, and Betty Rubiati. “Peralihan Hak Milik Menjadi Hak Pakai Atas Sarusun di Atas Tanah HGB Kepada Orang Asing Dihubungkan Dengan PP No. 103 Tahun 2015/Kepala BPN No. 29 Tahun 2016." ACTA DIURNAL Jurnal Ilmu Hukum Kenotariatan 2.1 (2018): 69-83.

Jacinda, Indah, Jason Jusuf, and Verlin Ferdina. "Penguasaan Tanah Di Indonesia Oleh Warga Negara Asing Melalui Perkawinan Campuran Dalam Falsafah Hukum." ADIL: Jurnal Hukum 9.2 (2019): 61-78. 
Latamu, Taufik Jan. "Kedudukan Hak Milik Atas Satuan Rumah Susun Sebagai Jaminan Kredit Perbankan." Lex Privatum 3.2 (2015): 22-27.

Mutiah, Siti. "Hak Kepemilikan atas Satuan Rumah Susun di atas Tanah Hak Guna Bangunan yang Berdiri di atas Tanah Hak Milik." Al-Qanun: Jurnal Pemikiran dan Pembaharuan Hukum Islam 21.1 (2018): 148-168.

Permadi, Iwan. "Kedudukan Badan Hukum Asing Dalam Pemilikan Tanah Di Indonesia." Jurnal Wacana 15.4 (2012): 40-48.

Rondonuwu, and Giovanni. "Kepastian Hukum Peralihan Hak Atas Tanah Melalui Jual Beli Berdasarkan PP Nomor 24 Tahun 1997 Tentang Pendaftaran Tanah." Lex Privatum 5.4 (2017): 114-121.

Santoso, Urip. Hukum Perumahan. Jakarta: Kencana Media, 2016.

Sumanto, Listyowati. “Kepemilikan Rumah Tempat Tinggal Atau Hunian Oleh Orang Asing Yang Berdomisili Di Indonesia." Jurnal Legislasi Indonesia 14.04 (2017): 455462.

Sutedi, Adrian. Tinjauan Hukum Pertanahan. Jakarta: Pradnya Paramita, 2009.

Tjitrosoedibio, R Subekti. Kamus Hukum. Pradnya Paramita, 2012.

Wafi, M Shafiyuddin, and R Suharto. "Perolehan Sertipikat Hak Milik Atas Satuan Rumah Susun (Studi Di Star Apartemen)." Diponegoro Law Journal 5.3 (2016): 1-13. 